\title{
SEASONAL VARIATIONS IN DISSOLVED HEAVY METALS IN THE KERITIS RIVER, CHANIA, GREECE
}

\author{
A.K. PAPAFILIPPAKI* \\ M.E. KOTTI \\ G.G. STAVROULAKIS
}

Received: 02/01/08

Accepted: 18/03/08

\author{
Laboratory of Water \& Soil Resources Quality Control \\ Technological Educational Institute of Crete \\ 73133 Chania, Greece
}

*to whom all correspondence should be addressed: e-mail: npapafilippaki@mail.chania.teicrete.gr

\section{ABSTRACT}

Agrochemicals, geochemical structure and industrial wastes create a potential source of heavy metal pollution in the aquatic environment. The porpuse of this study was to investigate the seasonal variations in five heavy metals $(\mathrm{Cu}, \mathrm{Zn}, \mathrm{Cd}, \mathrm{Pb}$ and $\mathrm{Cr}$ ) in the surface water of the Keritis river, one of the most important rivers in Chania, Greece. The surface water samples were colloected at 8 sampling sites in the Keritis river system. Seven sampling campaigns were carried out in each site in a 1-year period, during August 2004 to July 2005. Heavy metals were determined by using flame and furnace Atomic Absorption Spectrometry. Ancillary data included water temperature, $\mathrm{pH}$ and electric conductivity.

Significant variations were observed between the warm period (May to September) and the wet period (October to April), for the studied metals. Heavy metal concentrations were sufficiently higher in warm period than in wet period. The average concentrations in wet and warm period were: $\mathrm{Cu}\left(0.88 \mathrm{~g} \mathrm{I}^{-1} ; 6.62 \mathrm{~g} \mathrm{I}^{-1}\right), \mathrm{Cd}\left(0.005 \mu \mathrm{g} \mathrm{I}^{-1} ; 0.019 \mu \mathrm{g} \mathrm{I}^{-1}\right), \mathrm{Pb}\left(0.28 \mu \mathrm{g} \mathrm{I}^{-1}\right.$; $\left.2.59 \mu \mathrm{g} \mathrm{I}^{-1}\right)$, Cr $\left(1.44 \mu \mathrm{g} \mathrm{I}^{-1} ; 3.25 \mu \mathrm{g} \mathrm{I}^{-1}\right)$, and Zn $\left(4 \mathrm{\mu g} \mathrm{I}^{-1} ; 39 \mathrm{gg} \mathrm{I}^{-1}\right)$, respectively. The relative variability followed the order: $\mathrm{Zn}>\mathrm{Pb}>\mathrm{Cu}>\mathrm{Cd}>\mathrm{Cr}$. The seasonal variations may be due to either anthropogenic causes, such as agricultural practices, especially the use of fertilizers and biocides or wastewater discharge, or natural causes, such as water temperature, $\mathrm{pH}$, redox condition, or river flow. The water $\mathrm{pH}$ was lower in warm period than in wet period. The concentrations of $\mathrm{Cu}, \mathrm{Zn}, \mathrm{Cd}, \mathrm{Pb}$ and $\mathrm{Cr}$ were found to be positively related to the water $\mathrm{pH}$ in both periods. The water temperature was higher in the warm period and no strong, but remarkable correlations were found between the heavy metal concentrations and the temperature values for the warm and the wet period. Also, there was found no correlation between the heavy metal concentrations and the electrical conductivity.

KEYWORDS: Seasonal variations, River water, Heavy metals, Keritis, Greece

\section{INTRODUCTION}

Heavy metals are among the most common environmental pollutants, and their occurrence in waters and biota indicate the presence of natural or anthropogenic sources The main natural sources of metals in waters are chemical weathering of minerals and soil leaching. The anthropogenic sources are associated mainly with industrial and domestic effluents, urban storm, water runoff, landfill leachate, mining of coal and ore, atmospheric sources and inputs rural areas. (Kabata -Pendias and Pendias, 1992; Biney et al.,1994; Zarazua et al., 2006).

Water pollution by trace metals is an important factor in both geochemical cycling of metals and in enviromental health (Kabata -Pendias and Pendias, 1992). The existence of heavy metals in aquatic environments has led to serious concerns about their influence on plant and animal life. Metal nutritional requirements $(\mathrm{Cu}, \mathrm{Zn}$ etc.) differ substantially between species or elements, and optimum ranges of concentrations are generally narrow severe unbalances on metal proportions caused by exposure to elevated concentrations can cause death for organisms. Other elements ( $\mathrm{Pb}, \mathrm{Cd}$ etc.) exhibit extreme toxicity even at trace levels (Nicolau et al., 2006). 
All heavy metals exist in surface waters in colloidal, particulate, and dissolved phases (Osmond et al., 1995). Rivers are a dominant pathway for metals transport (Miller et al., 2003) and trace metals may become significant pollutants of many small riverine systems (Dassenakis et al., 1998). The behaviour of metals in natural waters is a function of the substrate sediment composition, the suspended sediment composition, and the water chemistry (Osmond et al., 1995). During their transport, the trace metals undergo numerous changes in their speciation due to dissolution, precipitation, sorption and complexation phenomena (Dassenakis et al., 1997; Akcay et al., 2003) which affect their behaviour and bioavailability (Nicolau et al., 2006).

Trace elements are easily influenced by environmental factors such as surface runoff, groundwater, dissolution from sediment, deposition from the atmosphere and anthropogenic pollutants. Hence, trace metals may be sensitive indicators for monitoring changes in the water environment. There are many reports on temporal changes, especially seasonal variations, in heavy metal concentrations in river waters (Iwashita and Shimamura, 2003). The purpose of this study was to estimate the seasonal variation of the dissolved $\mathrm{Cu}, \mathrm{Zn}, \mathrm{Cd}$, $\mathrm{Pb}$ and $\mathrm{Cr}$ between the wet and warm period in the Keritis river system and their correlations with $\mathrm{pH}$, water temperature and electrical conductivity in both periods.

\section{MATERIALS AND METHODS}

\subsection{Study area}

The Keritis' river is located in the north part of Chania Prefecture, on the island of Crete, Greece (Figure 1). It originates from the Mounts Lefka Ori and discharges into the Cretan Sea. The average water flowrate is $3500 \mathrm{~m}^{3} \mathrm{~h}^{-1}$ with high fluctuations between the winter and summer months. The total length of the main sector of the river is about $22 \mathrm{~km}$.

The drainage basin of the Keritis river system is 16,036 ha and it's the biggest hydrological basin in Chania Prefecture. The basin consists of about 10 villages and the population is approximately 7,000 . The area has a typical Mediterranean climate with mild winters and dry summers. The annual average temperature and rainfall are $19.96^{\circ} \mathrm{C}$ and $824 \mathrm{~mm}$, respectively. The rainy events are usually short but intense and promote high rates of surface runoff. The basin of Keritis is mainly an agricultural area. The most common cultivations are olive trees, citrus trees, vineyards and vegetables. In the area also, is developed light industry (olive mills, wineries and other agricultural factories) and in the coastal zone, where is the estuary of the Keritis river, there are many touristic units.

\subsection{Sampling and analysis}

The surface water samples were colloected at 8 sampling sites in the Keritis river system (Figure 1). Seven sampling campaigns were carried out in each site in a 1-year period, during August 2004 to July 2005. The four sampling campaigns were realised at the warm period (May to September) and the other three were carried out during the wet period (October to April). Water samples were collected in an acid-cleaned polyethylene bucket, after that, water samples were transferred in 2 I polypropylene bottles, and they were immediately transported in a portable refrigerator, to the laboratory at $\pm 4^{\circ} \mathrm{C}$.

Water temperature was measured at the sampling sites. Hydrogen ion activity $(\mathrm{pH})$ and electrical conductivity (EC) values were measured by a portable pHmeter and conductometer (SENSION 156 HACK), respectively.

For the heavy metal analysis, a 200-ml water sample was immediately filtered through a 0.45 $\mu \mathrm{m}$ membrane using a vacuum pumping system and transferred into an acid-cleaned 250-ml polypropylene bottle, and then $2 \mathrm{ml}$ of high-purity nitric acid was added to give a $\mathrm{pH}$ of $\sim 1$ (Cenci and Martin, 2004). Heavy metal concentrations were determined directly in the acidified filtrates by Atomic Absorption Spectrometry (Perkin Elmer, AAnalyst 700). Zinc was analyzed by Flame Atomic Absorption Spectrometry. Copper, lead, cadmium and chromium were determined by graphite furnace Atomic Absorption Spectrometry. All water samples were treated in duplicate. The relative standard deviations (RSD) of the methods and each run were $<3.5 \%$. In all cases, standards and blank were treated in the same way as the real samples to minimize matrix interferences during analysis. 


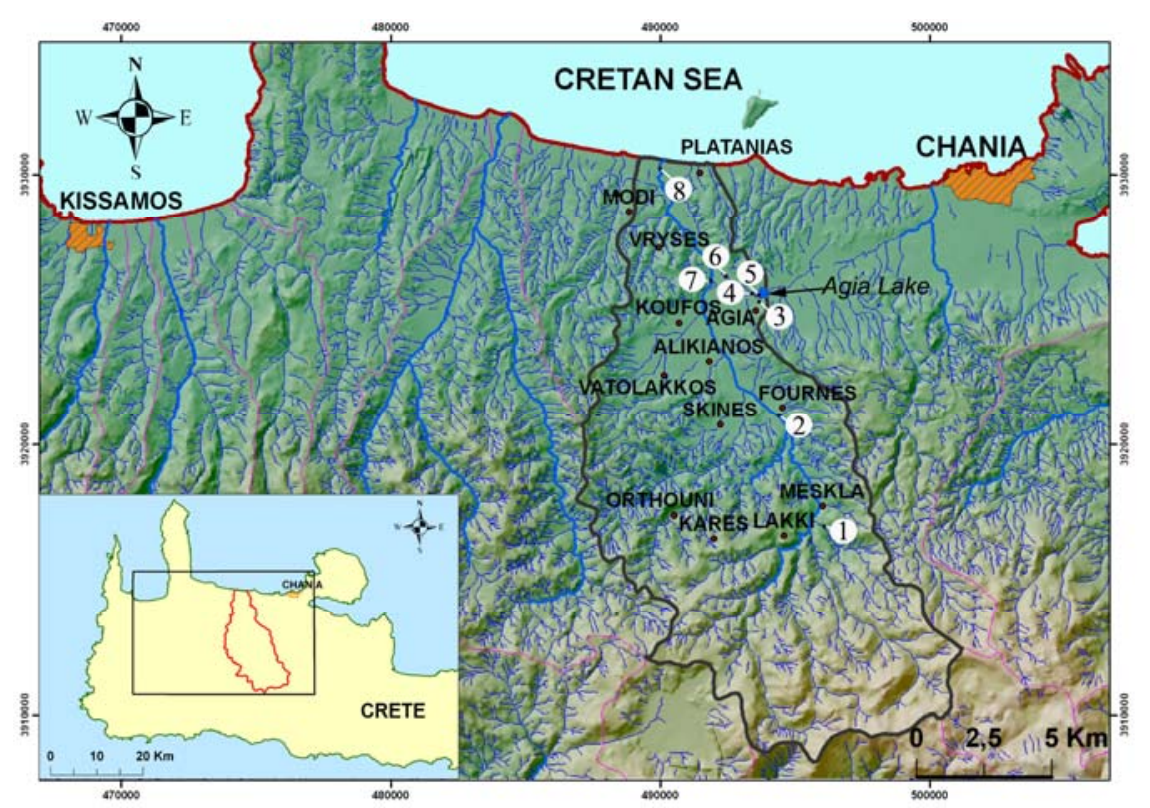

Figure 1. Location of the Keritis river system.

(The numbers in cycles show the surface water sampling sites)

\section{RESULTS AND DISCUSSION}

The values of the physicochemical parameters in Keritis river water during two different periods are given in Table 1 . The water temperatures were higher in the warm period from May to September due to meteorological conditions. The water $\mathrm{pH}$ was lower in the warm period than in the wet period. In general the $\mathrm{pH}$ of Keritis river water was alkaline. The values of the electric conductivity showed no significant variations between warm and wet period at the most of the sampling sites.

Table 1. Physicochemical parameters in warm and wet period in the Keritis river water

\begin{tabular}{ccccc}
\hline Period & Parameter & Min & Max & Average \\
\hline \multirow{3}{*}{ Warm } & Temperature $\left({ }^{\circ} \mathrm{C}\right)$ & 16.4 & 20.5 & 18.5 \\
& $\mathrm{pH}$ & 7.15 & 8.07 & 7.57 \\
& E.C. $\left(\mu \mathrm{S} \mathrm{cm}{ }^{-1}\right)$ & 258 & 1492 & 619 \\
\hline \multirow{2}{*}{ Wet } & Temperature $\left({ }^{\circ} \mathrm{C}\right)$ & 11.1 & 14.7 & 13.4 \\
& $\mathrm{pH}$ & 7.71 & 8.39 & 8.09 \\
& E.C. $\left(\mu \mathrm{S} \mathrm{cm}^{-1}\right)$ & 270 & 1377 & 620 \\
\hline
\end{tabular}

The studied dissolved metal concentrations in the Keritis' river during warm and wet period and their variation percentage are given in Table 2. The variation percentage was evaluated from the average values of the dissolved metal concentrations.

Table 2. Dissolved metal concentrations $\left(\mu \mathrm{g} \mathrm{I}^{-1}\right.$ ) and variation percentage (\%) in the Keritis river

\begin{tabular}{cccccc}
\hline Period & Element & Min & Max & Average & $\begin{array}{c}\text { Variation } \\
\text { Percentage }\end{array}$ \\
\hline Warm & $\mathrm{Cu}$ & 3.66 & 13.2 & 6.62 & \\
& $\mathrm{Zn}$ & 16 & 142 & 39 & \\
& $\mathrm{Cd}$ & $\mathrm{ND}$ & 0.042 & 0.019 & \\
& $\mathrm{~Pb}$ & 0.039 & 12.61 & 2.59 & \\
\hline Wet & $\mathrm{Cr}$ & 2.21 & 4.58 & 3.25 & 86.7 \\
& $\mathrm{Cu}$ & 0.5 & 1.45 & 0.88 & 89.7 \\
& $\mathrm{Zn}$ & $\mathrm{ND}$ & 11 & 4 & 73.7 \\
& $\mathrm{Cd}$ & $\mathrm{ND}$ & 0.019 & 0.005 & 89.2 \\
& $\mathrm{~Pb}$ & $\mathrm{ND}$ & 1.14 & 0.28 & 55.7 \\
\hline
\end{tabular}

ND: Non Determined (below detection limit). 
According to the variation percentage, the maximum seasonal decrease observed for $\mathrm{Zn}$ and the minimum for $\mathrm{Cr}$. The relative variability of the studied dissolved metals of the Keritis river followed the order: $\mathrm{Zn}>\mathrm{Pb}>\mathrm{Cu}>\mathrm{Cd}>\mathrm{Cr}$.

The solubility of trace metals in surface water is predominately controlled by the water $\mathrm{pH}$ (Osmond et al., 1995), water temperature (Iwashita and Shimamura, 2003), the river flow (Neal et al., 2000b; Iwashita and Shimamura, 2003; Olías et al., 2004) and the redox environment of the river system (Osmond et al., 1995; Iwashita and Shimamura, 2003). A lower $\mathrm{pH}$ increases the competition between metal and hydrogen ions for binding sites. A decrease in $\mathrm{pH}$ may also dissolve metal-carbonate complexes, releasing free metal ions into the water column (Osmond et al., 1995). Although the $\mathrm{pH}$ decrease was low in the Keritis river it may play a significant role in the dissolved metal increase in the warm period. A decreased redox potential, as is often seen under oxygen deficient conditions, will change the composition of metal complexes and release the metal ions into the overlying water (Osmond et al., 1995). Temperature impacts the rates of metabolism and growth of aquatic organisms, rate of plants' photosynthesis, solubility of oxygen in river water, and organisms' sensitivity to disease, parasites, and toxic materials. At a higher temperature, plants grow and die faster, leaving behind matter that requires oxygen for decomposition. Trace elements where are accumulated to phytoplankton may become soluble during the decay of plants (Kabata Pendias and Pendias, 1992). The seasonal variation of the water temperature in the Keritis River may influence the variability of the studied metals indirectly via biological activity (decay of phytoplankton) or due to possible decrease of dissolved oxygen which related to redox potential decrease. In wet period the intense rains cause an increase in the river flow, producing a dilution of the contaminants. During the mixing of large volumes of non contaminated runoff water, the $\mathrm{pH}$ increases and the sulphate and metal content decrease. When the river flow decreases during the warm period, the concentrations of contaminants begin to recover, reaching maxima in the summer due to sulphide-oxidising bacterial activity increasing with the temperature, and simultaneously, a concentrating effect of the dissolved pollutants occurs in the water due to water evaporation (Olías et al., 2004). There are no river flow data for all the studied sampling sites of the Keritis river. According to flow data where came from monitoring done by the local department of Ministry of Agriculture, the river flow at the sampling site 7 (Patelari), was about $7000 \mathrm{~m}^{3} \mathrm{~h}^{-1}$ in the winter (wet period) and $650 \mathrm{~m}^{3} \mathrm{~h}^{-1}$ in the summer (warm period). The relative high flow rate during the wet period due to enrichment with uncontaminated water from the springs and runoff from the mountains "Lefka Ori" may cause a dilution of heavy metal concentration.

The seasonal variation of electric conductivity was random and no seasonality was observed at any sampling site. Hence, electrical conductivity may not be a factor controlling the seasonal variation of the studied metals.

Temperature, $\mathrm{pH}$ and electric conductivity affect the contaminants fate in the river, control their speciation and thus their distribution within the dissolved or particulate fractions (Nicolau et al., 2006). In this study investigated the linear relationships between the studied physicochemical parameters and the dissolved metals of the sampling site of the Keritis river water on warm and wet period. An example of estimation of the linear relationships for $\mathrm{Cu}$ is given in Figure 2.

Table 3 shows the linear correlation coefficients $\left(R^{2}\right)$ between the studied metals and the physicochemical parameters in the Keritis' river.

The dissolved metals in both periods are significantly related to the water $\mathrm{pH}$ (except $\mathrm{Pb}$ in warm period). Also the correlations between the studied metals and the temperature were found no strong but remarkable. In addition there was found no correlation between the dissolved metals and the electrical conductivity in the sampling sites of the Keritis' river (except $\mathrm{Pb}$ in wet period). 

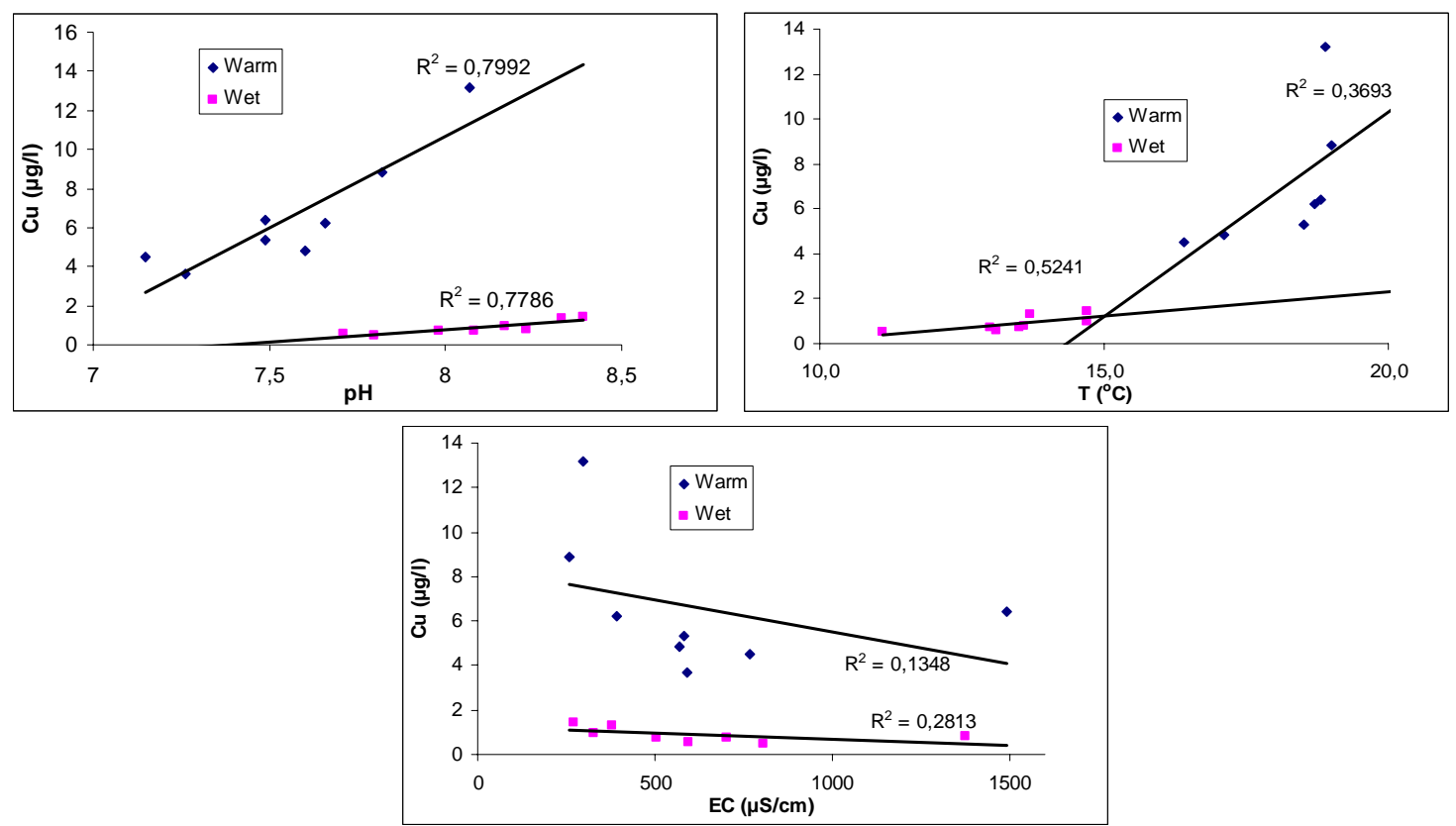

Figure 2. Linear relationships between dissolved $\mathrm{Cu}$ and physicochemical parameters in the Keritis river

Table 3. $\mathrm{R}^{2}$ between dissolved metals - physicochemical parameters in the Keritis river

\begin{tabular}{ccccccc}
\hline Period & Parameter & $\mathrm{Cu}$ & $\mathrm{Zn}$ & $\mathrm{Cd}$ & $\mathrm{Pb}$ & $\mathrm{Cr}$ \\
\hline \multirow{3}{*}{ Warm } & Temperature $\left({ }^{\circ} \mathrm{C}\right)$ & 0.3693 & 0.5336 & 0.4086 & 0.5524 & 0.4696 \\
& $\mathrm{pH}$ & 0.7992 & 0.6133 & 0.7189 & 0.2143 & 0.7323 \\
& E.C. $\left(\mu \mathrm{S} \mathrm{cm}{ }^{-1}\right)$ & 0.1348 & 0.0097 & 0.2154 & 0.0035 & 0.0928 \\
\hline \multirow{2}{*}{ Wet } & Temperature $\left({ }^{\circ} \mathrm{C}\right)$ & 0.5241 & 0.4062 & 0.4574 & 0.4589 & 0.2598 \\
& $\mathrm{pH}$ & 0.7786 & 0.6886 & 0.5292 & 0.609 & 0.7104 \\
& E.C. $\left(\mu \mathrm{S} \mathrm{cm}{ }^{-1}\right)$ & 0.2813 & 0.1535 & 0.0019 & 0.8048 & 0.0212 \\
\hline
\end{tabular}

\section{CONCLUSIONS}

This study investigated the seasonal variation of $\mathrm{Cu}, \mathrm{Zn}, \mathrm{Cd}, \mathrm{Pb}$ and $\mathrm{Cr}$ in the Keritis river, one of the most important rivers in Chania - Greece. Significant variations were found between warm and wet period for the studied metals. The relative variability followed the order $\mathrm{Zn}>\mathrm{Pb}>\mathrm{Cu}>\mathrm{Cd}>\mathrm{Cr}$. The seasonal variation of the studied metals maybe related to the variations of water $\mathrm{pH}$, river flow, water temperature and redox conditions. The electrical conductivity seams to have no correlation with the seasonal variations of dissolved metals. Significant relationships where observed between the heavy metals concentration and the water $\mathrm{pH}$ in both periods. Also the correlation between the studied metals and the water temperature were satisfying, but with the electrical conductivity was observed no remarkable relationship.

\section{AKNOWLEGEMENTS}

The present research is a part of the project entitled "Multiparametric identification system development for the origin of water resources in karstic basins: Application in the Keritis river basin (Natura 2000-Chania)" which is co-funded by the European Social Fund and National Resources, Operational Program for Education and Initial Vocational Training -ARCHIMEDES II: "Support of Research Teams of Technological Educational Institutes. 


\section{REFERENCES}

Akcay H., Oguz A. and Karapire C., (2003), Study of heavy metal pollution and speciation in Buyak Menderes and Gediz river sediments, Water Res, 37, 813-822.

Biney C., Amuzu A.T., Calamari D., Kaba N., Mbome I.L., Naeve H., Ochumba P.B.O., Osibanjo O., Radegonde V. and Saad M.A.H., (1994), Review of pollution in the African aquatic environment, FAO, Rome.

Cenci R.M. and Martin J.M., (2004) 'Concentration and fate of trace metals in Mekong River Delta' Science of the Total Environment, 332, 167-182.

Dassenakis M., Scoullos M. and Gaitis A., (1997), Trace metals transport and behaviour in the Mediterranean estuary of Archeloos river, Mar. Pollut. Bull., 34, 103-111.

Dassenakis M., Scoullos M., Foufa E., Krasakopoulou E., Pavlidou A. and Kloukiniotou M., (1998), Effects of multiple source pollution on a small Mediterranean river Appl. Geochem., 13, 197211.

Iwashita M., Shimamura T., (2003), Long-term variations in dissolved trace elements in the Sagami River and its tributaries (upstream area), Japan, The Science of the Total Environment, 312, 167-179.

Kabata -Pendias A. and Pendias H., (1992), Trace elements in soils and plants, CRS Press , Boca Raton

Miller C.V., Foster G.D. and Majedi B.F., (2003), Baseflow and stormflow metal fluxes from two small agricultural catchments in the coastal plain of Chesapeake Bay Basin, United States, Appl. Geochem., 18, 483-501.

Neal C., Williams R.J., Neal M., Bhardwaj L.C., Wickham H., Harrow M. and Hill L.K., (2000b), The water quality of the River Thames at a rural site downstream of Oxford, Sci Total Environ., 252, 441-457.

Nicolau R., Galera - Cunha A. and Lucas Y., (2006), Transfer of nutrients and labile metals from the continent to the sea by a small Mediterranean river, Chemosphere, 63, 469-476.

Olías M., Nietob J.M., Sarmientob A.M., Ceróna J.C. and Cánovasa C.R., (2004), Seasonal water quality variations in a river affected by acid mine drainage: the Odiel River (South West Spain), Science of The Total Environment, 333, 267-281.

Osmond, D.L., Line D.E., Gale J.A., Gannon R.W., Knott C.B., Bartenhagen K.A., Turner M.H., Coffey S.W., Spooner J., Wells J., Walker J.C., Hargrove L.L., Foster M.A., Robillard 'P.D. and Lehning D.W., (1995), Water, Soil and Hydro-Environmental Decision Support System, URL:www.water.ncsu.edu/watersheds/info /hmetals.html

Zarazua G., Ávila-Pérez P., Tejeda S., Barcelo-Quintal I. and Martínez T., (2006), Analysis of total and dissolved heavy metals in surface water of a Mexican polluted river by Total Reflection X-ray Fluorescence Spectrometry, Spectrochimica Acta Part B: Atomic Spectroscopy, 61, 1180-1184. 